\title{
"Magnetic Properties and Induction Heating Ability Studies of Spinal Ferrite Nanoparticles for Hyperthermia Treatment of Tumors"
}

\author{
D.A. Rayan ${ }^{1}$ and M.M. Ismail ${ }^{2}$ \\ ${ }^{1}$ Central Metallurgical Research \& Development Institute (CMRDI), P.O. Box: 87 \\ Helwan, 11421, Cairo, ${ }^{2}$ Physics Department, Faculty of Science, Al-Azhar University, \\ Nasr City, Cairo, Egypt.
}

\begin{abstract}
T this research synthesizesnanocrystalline $\mathrm{CuFe}_{2} \mathrm{O}_{4}$ spinel structure using co-precipitation method. X-ray diffraction (XRD), transmissionelectron microscopy (TEM), and vibrating sample magnetometer (VSM) are utilized in order to study crystalline size, lattice parameters, microstructure and optical and magnetic properties of the formed nanopowders.Hyperthermia is one of the most promising approaches in cancer therapy. The most commonly used heating method in the clinical setting is capacitive heating that uses a radiofrequency $(\mathrm{RF})$ electric field.The induction heating behavior and heating properties of the $\mathrm{CuFe}_{2} \mathrm{O}_{4}$ nanoparticles in an alternating magnetic field at $150-300 \mathrm{kHz}$ were estimated.The resultmaking $\mathrm{Cu}$ ferrite appropriate for hyperthermia treatment of cancer.These results will help us to optimize the conditionsfor tumor treatment by magnetic nanoparticles.
\end{abstract}

Keywords: $\mathrm{CuFe}_{2} \mathrm{O}_{4}$; Spinel Ferrites; Optical properties; Magnetic Properties, HeatInduction.

\section{Introduction}

Spinels of the type $\mathrm{M}^{2+} \mathrm{M}_{2}^{3+} \mathrm{O}_{4}$ attract agreatdealofinterest for theirdiverse practicalapplications [1]. InthecaseofM ${ }^{3+}=\mathrm{Fe}$, the resultingspinelferriteshavingageneralchemicalcomposition $\mathrm{MFe}_{2} \mathrm{O}_{4}$ ( $\mathrm{M}=\mathrm{Co}, \mathrm{Ni}, \mathrm{Mn}, \mathrm{Fe}, \mathrm{Cu}, \mathrm{Zn}$,etc.), and they havea face- centeredcubic (FCC) closepackingstructure [2]. Spinelferritesareamongthemost widely usedmagneticmaterials and exhibit interestingmagnetic, magneto-resistive andmagneto-opticalproperties. Thedevelopment ofuniformspinelferritenanocrystalshasbeenintensively pursued in the applicationsofmagneticfluids [3], catalysis [4,5], biotechnology/biomedicine [6,7], magneticresonanceimaging $[8,9]$, datastorage $[10,11]$ and microwaveabsorption [12]. There are several methods for synthesizing nanosized spinel ferrite particles such as co-precipitation [13], hydrotherh mal method [14,15], sol-gel [16,17], combustion method [17,18], precursor method [19], microemulsion method [20], ball milling method [21] and mechano-chemical method [22].Many reports proved thatt heproperty of spinelferritescanbe improved bydopingmetalelementsinMFe $\mathrm{O}_{4} \mathrm{OW}-$ ing totheir enhanced crystalanisotropy [23]. The substitution of various cations such as magnetic and nonmagneticat different sub-lattices in ferrite materials rendersdifferent kinds of magnetic and electrical properties [24-26]. Severalcations such as $\mathrm{Zn}^{2+}, \mathrm{Cu}^{2+}, \mathrm{Ti}^{4+} \mathrm{Co}^{2+}$ and $\mathrm{Y}^{3+}$ have been attemptedby many researchers in order to improve the electrical and magneticproperties of spinel ferrites [27-30].The morphology and size of the synthesized ferrite can be tailored by different preparation methods.

\section{Experimental \\ Materials and Preparation}

The synthesis procedure is as the follow: A mixture of iron (III) nitrate nonahydrate, $\mathrm{Fe}\left(\mathrm{NO}_{3}\right)_{3} .9 \mathrm{H}_{2} \mathrm{Oand}$ copperchloridehexahydrate with the $\mathrm{Fe}^{3+} \mathrm{Cu}^{2+}$ molar ratios 2:1 was dissolved in deionized water. The produced solution was treated with $5 \mathrm{M} \mathrm{NaOH}$ to form a precipitate at $\mathrm{pH}$ 12. The produced slurry was filtered, washed and dried at $100{ }^{\circ} \mathrm{C}$. The formed precursor powders were annealing temperature at $1000{ }^{\circ} \mathrm{C}$ for $2 \mathrm{hrs}$ in static air atmosphere.

\section{Characterization}

The crystalline phases present in the different annealed samples were identified by X-ray diffraction (XRD) on a Brucker axis D8 diffractometer using $\mathrm{Cu}-\mathrm{K}_{\alpha}(\lambda=1.5406)$ radiation and secondary monochromator in the range $2 \theta$ from $10^{\circ}$ to $80^{\circ}$ operating at $40 \mathrm{kV}$ and $30 \mathrm{~mA}$ at a rate

*Corresponding author : diaa001@yahoo.com

DOI : 110.21608/ejbbe.2019.5193.1022

C2018 Nathional Information and Documentaion Center (NIDOC) 
of $2 \% \mathrm{~min}$. The crystallite sizes of the produced mayenite for the most intense peak (3 11 1) plane determined from the X-ray diffraction data using the Debye-Scherrer formula [31]:

$d_{R X}=k \lambda / \beta \cos \theta$

wher e $d_{R X}$ is the crystallite size, $k=0.9$ is a correction factor to account for particle shapes, $\beta$ is the full width at half maximum (FWHM) of the most intense diffraction peak (4 20 ) plane, $\lambda$ is the wavelength of $\mathrm{Cu}$ target $=1.5406 \AA$, and $\theta$ is the Bragg angle. Fourier transform infrared spectroscopy (FTIR) by using a FTIR Thermo Electron Magna 760. The micrographs of produced samples were examined by direct observation via filed emission scanning electron microscope (FE-SEM) model JEOL instrument (Japan) model JSM-7800F. The UV-Vis absorption and diffuse reflectance spectrum were recorded at room temperature using UV-VIS-NIR spectrophotometer (Jasco-V-570 spectrophotometer, Japan) fitted with integrating sphere reflectance unit (ISN) in the wavelength range $200-2000 \mathrm{~nm}$. The magnetic properties of the powders were measured at room temperature using a vibrating sample magnetometer (VSM, 7410 Lakeshore, USA) in a maximum applied field of $20 \mathrm{KOe}$. From the obtained hysteresis loops, the saturation magnetization $\left(M_{\mathrm{s}}\right)$, remanence magnetization $\left(M_{\mathrm{r}}\right)$ and the coercive field $\left(H_{\mathrm{c}}\right)$ were determined.

\section{Hyperthermia system}

hyperthermia system consist of zero voltage switching [ZVS] induction high frequency heating board, an induction coil with [10 turns] of inner diameter [2 $\mathrm{cm}$ ], and cut around hollow cylinder inner side, digital DC power supply and oscilloscope. ZVS converter DC current to AMF and insulating sample holder placed within a solenoid induction copper coil. The induction solenoid coils produce a uniform magnetic field inside volume within the coil. The coil formed from cylindrical sections of copper plate with other design elements that enhance performance over a comparable solenoid.

We adjust the voltage of DC power supply to get the desired frequency (195 kHZ) for inducing hyperthermia. To avoid heat lost by convection we coated the tube by polyurethane foam (PUR) as a thermal insulator.

\section{Magnetic heating induction study}

Four different concentrations $(20 \mathrm{mg} / \mathrm{ml}, 40$ $\mathrm{mg} / \mathrm{ml}, 60 \mathrm{mg} / \mathrm{ml}$ and $80 \mathrm{mg} / \mathrm{ml}$ ) of the $\mathrm{CuFe} 2 \mathrm{O} 4$ under investigation were suspended in $1 \mathrm{ml}$ of Egypt. J. Biophys. Biomed. Engng. Vol., 19 (2018) double distilled water. The vials were ultra-sonicated in water bath sonicatorfor $20 \mathrm{~min}$ at $40{ }^{\circ} \mathrm{C}$ , and then the suspension was placed in the coil center without touching the walls for $10 \mathrm{~min}$ of the sample with desired magnetic field $(H) 9.5$ Oe.The temperature increasing recoded for the different concentrations and graphs it to show the behavior of different concentration in inducing hyperthermia.

\section{$\underline{\text { Result and Dissection }}$}

$X$-ray diffraction analysis

The structure and phase purity of as prepared products were confirmed by analyzing the observed powder X-ray diffraction (XRD) patterns. The observed powder XRD pattern of the $\mathrm{CuFe}_{2} \mathrm{O}_{4}$ nanoparticles was shown in Fig. 1. All the observed reflections of the $\mathrm{Cu}$ ferrite $\left(\mathrm{CuFe}_{2} \mathrm{O}_{4}\right)$ samples could be assigned to cubic spinel lattice indicating their single phase nature and the planes in the diffraction patterns confirm the formation of pure cubic spinel ferrite structureof $\mathrm{CuFe}_{2} \mathrm{O}_{4}$ phase (JCPDS \# 08-0234) for all samples without any impurity or secondary phase [56].The average crystallite sizes ' $t$ ' the lattice constant ' $a$ ' andtheoretical density ' $d_{x}$ ' of the samples are listed in Table 1. It is clear that Table 1 the crystallite size and lattice parameter, for all samples, seems to be independent of the type of the substituted $\mathrm{Mn}^{2+}$ ions. Crystallite size for each sample was calculated using the Scherrer formula which is considering the most intense peak (3 111$)$.

The broadened diffraction peaks can be attributed to the nanocrystallite size of as prepared product. Unit cell parameters i.e. lattice parameter (a) was calculated by indexing the observed reflections of the XRD patterns by applying the following equation [32]:

$a=d \sqrt{h^{2}+k^{2}+l^{2}}$

The X-ray density or theoretical density was estimated by using the relation [33]:

$d x=\sum \frac{A}{N x V}$

where $A$ is sum of the atomic weights of all the atoms in the unit cell, $V$ is volume of the unit cell and $N$ is the Avogadro's number. Since each primitive unit cell of the spinel structure contains eight molecules, the theoretical density, $\mathrm{d} x$ was determined according to the following relation [34]: 
$d x=\frac{8 / V I}{N \sigma^{3}}$

(4)

Where $M$ is molecular weight of the sample, $N$ the Avogadro's number, a lattice parameter, 8 represents the number of molecules per unit cell and $a^{3}$ is the volume of the cubic unit cell.

The mean ionic radii of the A-and B-sublattices $\left(R_{A}\right.$ and $\left.R_{B}\right)$ can be calculated for all samples using the cation distribution and the relations [35]:

$$
\begin{aligned}
& R_{A}=(0.5-x) r_{\mathrm{Zn}^{2+}}+x r_{\mathrm{CO}^{2+}}+0.5 r_{\mathrm{Fe}^{3+}} \\
& R_{B}=0.5 r_{\mathrm{Ni2}+}+z r_{\mathrm{Y}^{3+}}+(0.5-z) r_{\mathrm{Fe} 3+}
\end{aligned}
$$

where $r$ denotes to the ionic radius. The calculated values are given in Table 2. It is obvious that the trend of $R_{A}$ and $R_{B}$ decrease with $x$, which may be due to the substitution process. The oxygen positional parameter $\mathrm{u}$ can be determined using the relation [35]:

$R_{A}=a \sqrt{3}(u-0.25)-r_{o}$

wherer ${ }_{0}$ is the $\mathrm{O}^{2-}$ radius. The obtained value of $u$ was $\sim 0.386$ for all samples. The tetrahedral bond length $d_{A L}\left(d_{A-O}{ }^{2-}\right)$ and the octahedral bond length $d_{B L}\left(d_{B-O}{ }^{2-}\right)$ can be calculated by the relations [35]:

$d_{A L}=a \sqrt{\mathbf{3}(u-0.25)}$

$$
d_{B L}=a\left(3 u^{2}-\frac{11}{4} u+\frac{43}{64}\right)^{1 / 2}
$$

The tetrahedral edge $d_{A E}$ and the octahedral edge $d_{B E}$ and unshared edge $d_{B E U}$ can be determined using the relations [35]:

$$
\begin{gathered}
d_{A E}=a \sqrt{2}(2 u-0.5) \\
d_{B E}=a \sqrt{2(1-2 u)} \\
d_{B L}=a\left(4 u^{2}-3 u+\frac{11}{16}\right)^{1 / 2}
\end{gathered}
$$

The distance between the magnetic ions $\mathrm{Co}^{3+}$ and $\mathrm{Fe}^{3+}$ (hopping lengths) can be calculated by the relations $L_{A}=a_{t}(3 / 4)^{1 / 2}$ and $L_{b}=a_{t}(2 / 4)^{1 / 2}$ for A- and B- sublattices [35]. The determined values are listed in Table 2. Table 2 illustrates that the trends of $R_{A}, R_{B}, d_{A L}, d_{B L}, d_{A E}, d_{B E}, d_{B E U}, L_{A}$ and $L_{B}$ reflect. This is assigned to the substitution process and cation distribution. The values of $u$ are higher than the standard values (0.375), which may point to a trigonal distortion of the B-site coordination. It may be due to the oxygen dissociation through the samples during the preparation.

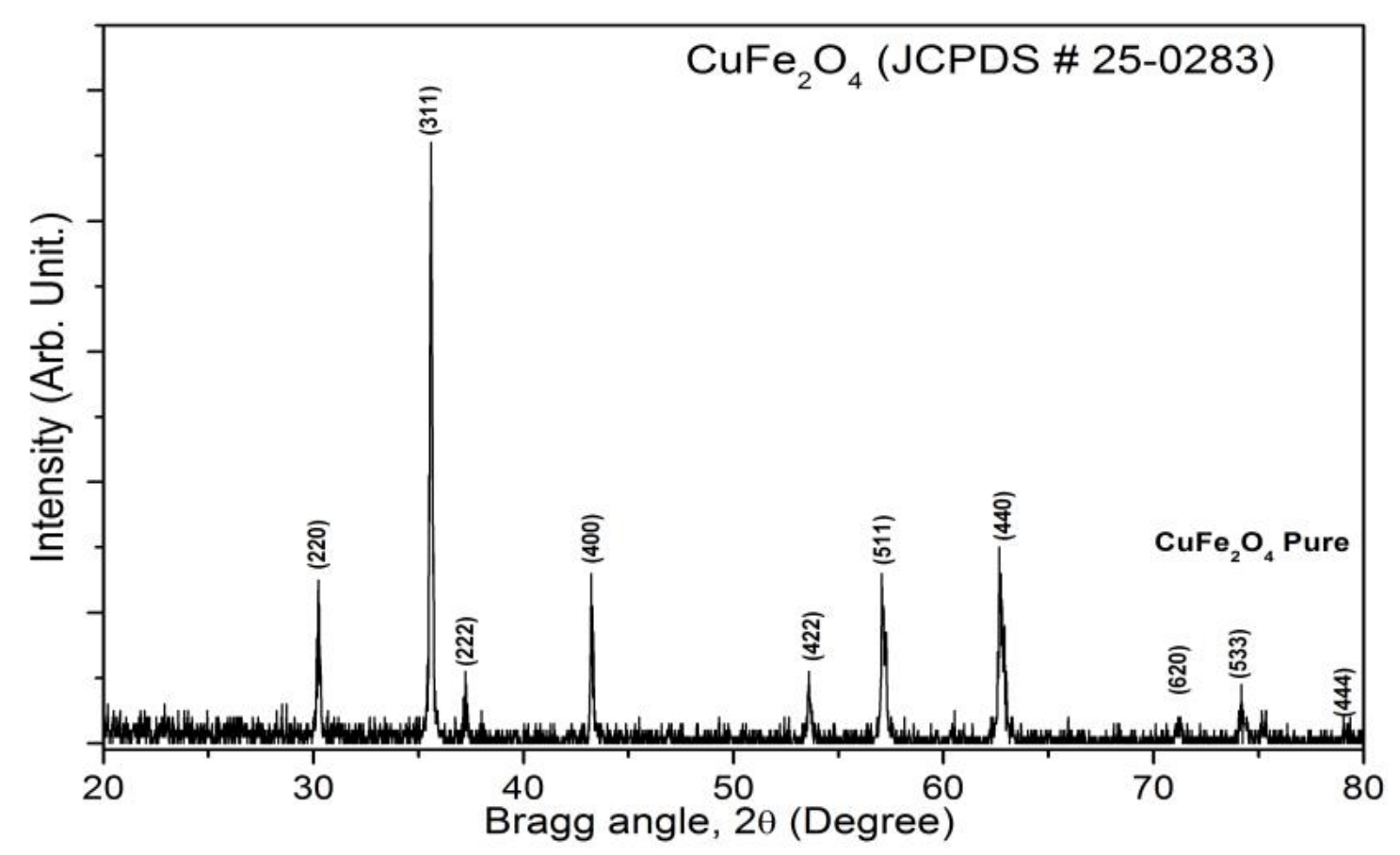

Fig. 1. XRD patternsof $\mathrm{CuFe}_{2} \mathrm{O}_{4}$ nanopowders. 
TABLE 1. Crystallite size (t), Lattice constant (a), Lattice volume (V), theatrical density $\left(d_{x}\right)$ and band gap energy $\left(\mathrm{E}_{\mathrm{g}}\right)$ of $\mathrm{CuFe}_{2} \mathrm{O}_{4}$ nanoparticles.

\begin{tabular}{|c|c|c|c|c|c|}
\hline Parameters & $\begin{array}{c}\text { Crystallite } \\
\text { size, } \\
\mathbf{t}(\mathbf{n m})\end{array}$ & $\begin{array}{c}\text { Lattice } \\
\text { constant, } \\
\mathbf{a}(\AA)\end{array}$ & $\begin{array}{c}\text { Lattice } \\
\text { volume, } \\
\mathbf{V}\left(\AA^{3}\right)\end{array}$ & $\begin{array}{c}\text { X-ray } \\
\text { density, } \\
\boldsymbol{d}_{x}\left(\mathbf{g} / \mathbf{c m}^{3}\right)\end{array}$ & $\begin{array}{c}\text { Band gap energy, } \\
\boldsymbol{E}_{g}(\mathbf{e V})\end{array}$ \\
\hline $\mathbf{C u F e}_{2} \mathbf{O}_{4}$ & 100.8 & 8.349 & 581.970 & 5.310 & 1.14 \\
\hline
\end{tabular}

TABLE 2. The obtainedlatticeparameters, theionicradiioftheA-andB-sites $\left(R_{A}, R_{B}\right)$, the A-andB-sitebondlengths $\left(d_{A L}, d_{B L}\right)$, the tetrahedraledge $\left(d_{A E}\right)$ and the octahedral shared andunsharededges $\left(d_{B E}, d_{B E U}\right)$ and are hoppinglengthsatA-andB-sites $\left(\mathrm{L}_{\mathrm{A}}, \mathrm{L}_{\mathrm{B}}\right)$ of $\mathrm{CuFe}_{2} \mathrm{O}_{4}$ nanoparticles.

\begin{tabular}{|c|c|c|c|c|c|c|c|c|c|}
\hline 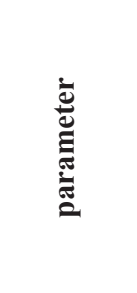 & 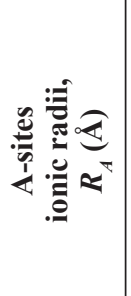 & 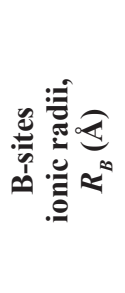 & 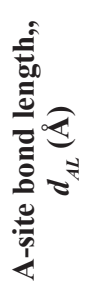 & 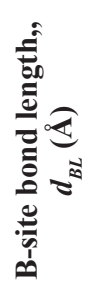 & 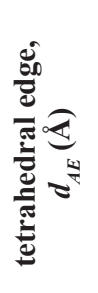 & 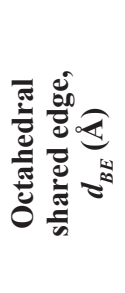 & 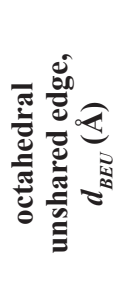 & 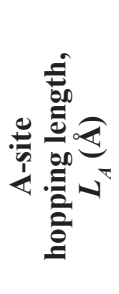 & 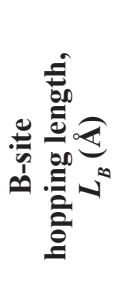 \\
\hline $\mathrm{CuFe}_{2} \mathrm{O}_{4}$ & 0.575 & 1.170 & 1.975 & 2.005 & 3.225 & 2.698 & 1.051 & 7.254 & 5.923 \\
\hline
\end{tabular}

Transmission electron microscopy analysis

The high-resolution transmission electron microscope (HRTEM) images in Fig. 2 showsize, shape and distribution of zinc ferrite prepared by the co-precipitation method at $1000^{\circ} \mathrm{C}$ at $2 \mathrm{~h}$. The first view showed that a group of very fine crystals self-organized and the large cubic structure morphology becomes the dominant and the particle size increased to $278 \mathrm{~nm}$ length and 503 nm width.

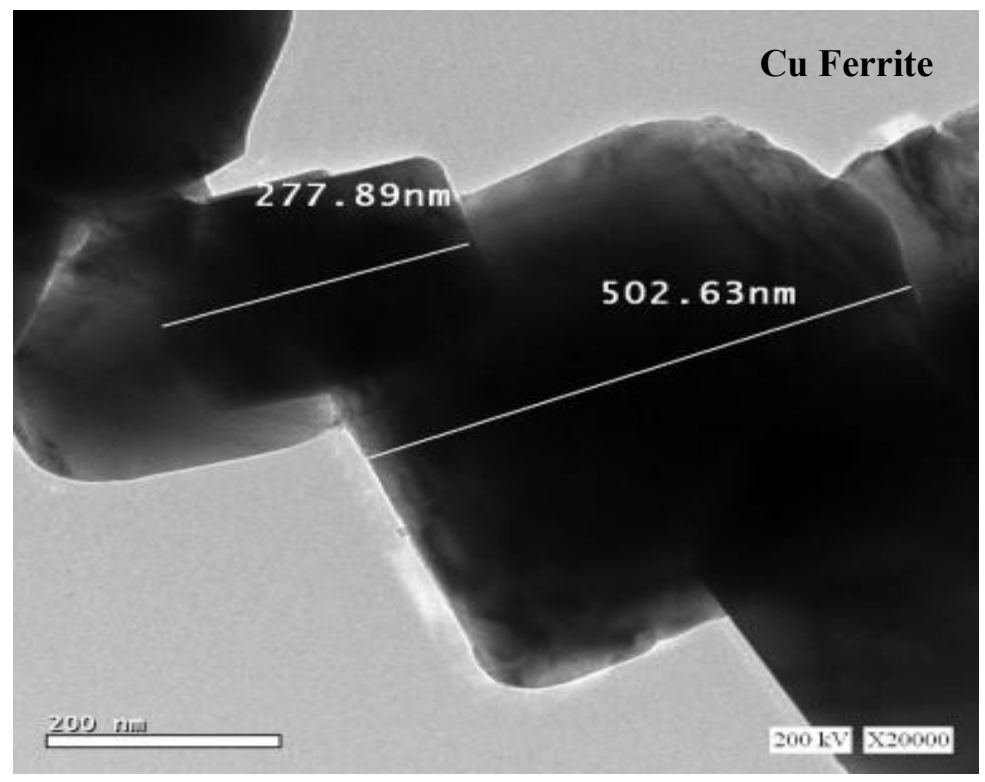

Fig. 2. TEM micrographsofCuFe $\mathrm{O}_{4}$ nanopowders.

Egypt. J. Biophys. Biomed. Engng. Vol., 19 (2018) 


\section{Optical properties}

UV-Vis-NIR Spectra

The optical properties of the powders for annealed samples were examined using UVVis-NIR spectrophotometer using integrating sphere unit. Fig. 3 depicts the absorbance and reflectance spectrums of $\mathrm{CuFe}_{2} \mathrm{O}_{4}$ nanopowders for $1000{ }^{\circ} \mathrm{C}$ for $2 \mathrm{~h}$ whereas The as deposited sample was exhibited the lowest optical reflectivity of around $45-10 \%$ in the infrared (IR) and visible regions. Further increasing in annealing temperature was found to enhance the average reflectivity of around $62-12 \%$ in the IR and visible regions, respectively. Additionally, the absorption peaks were corresponding to the characteristic peak of copper and iron ions.
Three bands were related to ${ }^{2} \mathrm{~B}_{2 \mathrm{~g}} \rightarrow{ }^{2} \mathrm{~B}_{1 \mathrm{~g}},{ }^{2} \mathrm{~A}_{1 \mathrm{~g}}$ $\rightarrow{ }^{2} \mathrm{~B}_{1 \mathrm{~g}}$ and ${ }^{2} \mathrm{E}_{\mathrm{g}} \rightarrow{ }^{2} \mathrm{~B}_{\mathrm{lg}}$ energy transitions of octahedral symmetry copper ion for pure copper oxide [38]. The first two transitions were very close in energy and often appeared in the form of one broad band profile in near-infrared. The third band was observed in the visible region which exhibited a broad optical absorption band around $780 \mathrm{~nm}$, assigned to the ${ }^{2} \mathrm{E}_{\mathrm{g}} \rightarrow{ }^{2} \mathrm{~B}_{1 \mathrm{~g}}$ transition imputed to Jahn-Teller splitting of $\mathrm{d}$ levels of copper ions [38]. Otherwise, three transition bands ${ }^{6} \mathrm{~A}_{1 \mathrm{~g}}(\mathrm{~S}) \rightarrow{ }^{4} \mathrm{~T}_{1 \mathrm{~g}}(\mathrm{G})\left(v_{1}\right),{ }^{6} \mathrm{~A}_{1 \mathrm{~g}}(\mathrm{~S}) \rightarrow{ }^{4} \mathrm{~T}_{2 \mathrm{~g}}(\mathrm{G})$ $\left(v_{2}\right)$ were assigned; $v_{1}$ at $950 \mathrm{~nm}$ whereas $v_{2}$ at 550 to $650 \mathrm{~nm}$ usually as a shoulder. Indeed, the bands corresponding to ${ }^{6} \mathrm{~A}_{1 \mathrm{~g}}(\mathrm{~S}) \rightarrow{ }^{4} \mathrm{~A}_{1 \mathrm{~g}}(\mathrm{G})$, ${ }^{4} \mathrm{E}_{\mathrm{g}}(\mathrm{G})\left(v_{3}\right)$ was deduced around $450 \mathrm{~nm}[39]$.
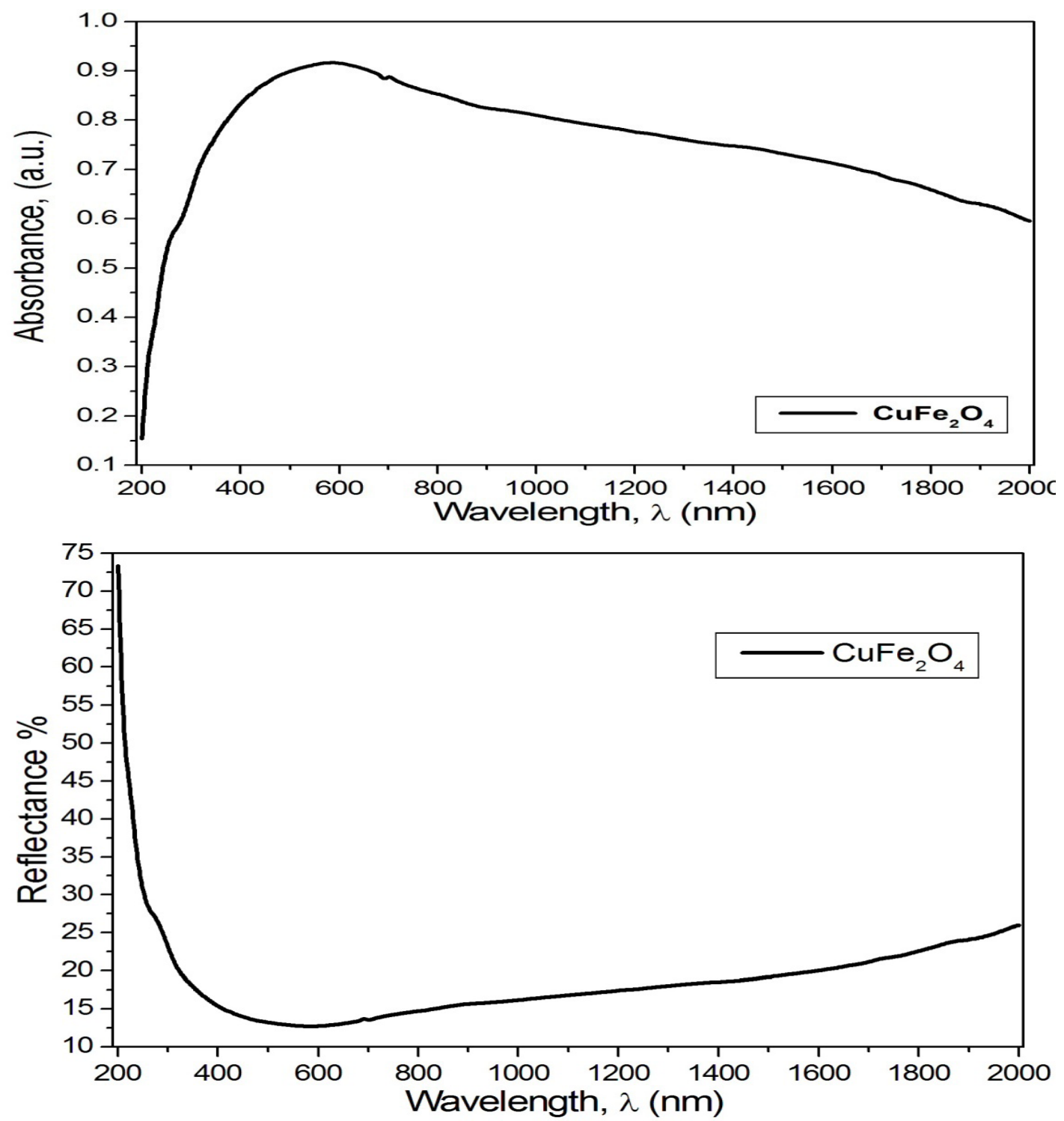

Fig. 3. Optical absorbance diffuse and reflectance spectra of $\mathrm{CuFe}_{2} \mathrm{O}_{4}$ nanoparticles . 
In the limiting case of an infinitely powder samples, thickness and sample holder have no influence on the value of reflectance $(R)$. In this case, the Kubelka-Munk equation at any wavelength becomes $[40,41]$ :

$F(R \infty)=(100-R) /(2 R)$

$F(R \infty)$ is the so-called remission or KubelkaMunk function. In the parabolic band structure, the band gap $(E g)$, and absorption coefficient $(\alpha)$, of a direct band gap semiconductor are related through the well known equation [42]:

$\alpha h v=A(h v-E g)^{1 / n}$

Where $\alpha$ is the linear absorption coefficient of the material, $h v$ is the photon energy and $A$ is proportionality constant. When the material scatters in perfectly diffuse manner (or when it is illuminated at $60 \pm$ incidence), the $\mathrm{K}-\mathrm{M}$ absorption coefficient $K$ becomes equal to $2 \alpha(K=2 \alpha)$. In this case, considering the K-M scattering coefficient $S$ as constant with respect to wavelength, and using the remission function in Eq. (14) we obtain the expression $[43,44]$ :

$(h v F(R \infty))^{n}=B(h v-E g)$

Therefore, obtaining F (Rœ) from Eq. (15) and plotting the $[\mathrm{F}(\mathrm{R} \infty) \mathrm{h} v]^{2}$ against $\mathrm{h} v$, the band gap energy $\mathrm{E}_{\mathrm{g}}$ of a powder sample can be extracted easily. The band gap energy of $\mathrm{CuFe}_{2} \mathrm{O}_{4}$ nanoparticles after Kubelka-Munk treatment was shown in Fig. 4. The direct band gap energy ofCuFe $\mathrm{O}_{4}$ sample was $1.14 \mathrm{eV}$ valuewas summarized and listed in Table 1.

\section{Magnetic properties}

The magnetization of the produced sampleof $\mathrm{CuFe}_{2} \mathrm{O}_{4}$ nanoferritesnanopowderswas measured at room temperature under an applied field of 20 KOe and the hysteresis loops were determined. Plots of magnetization (M) as a function of the magnetic field $(\mathrm{H})$ were plotted in Fig.5 and the corresponding data are collected in Table 3. The as-prepared products exhibited soft-magnetic properties. The values of saturation magnetizan tion $(\mathrm{Ms})$, coercivity $(\mathrm{Hc})$ and remanence $(\mathrm{Mr})$ are found to be in the range of (33.623) em $\mu / \mathrm{g}$, (2.3627) em $\mu / g$, (71.489) Oe respectively.The squareness ratiosforallthesampleswerealso calculated from Ms and Mrdata, and the calculatedvalues are listedin Table 3.

\section{Magnetic heating induction ability}

The characteristic temperature-time evolution of the sample under fixed magnetic field strength $0.75 \mathrm{KA} / \mathrm{m}$, at $195 \mathrm{KHz}$. After the magnetic field is switched on, the temperature initially rise the heating ability of the magnetic nanoparticles was found to be dependent on its concentration as in Table 4 in addition to its magnetic properties. The Nano-crystalline $\mathrm{Cu}$ ferrite show notice rise in temperature in short time $(10 \mathrm{~min})$ as shown in Fig.6 ready for killing tumor cells.

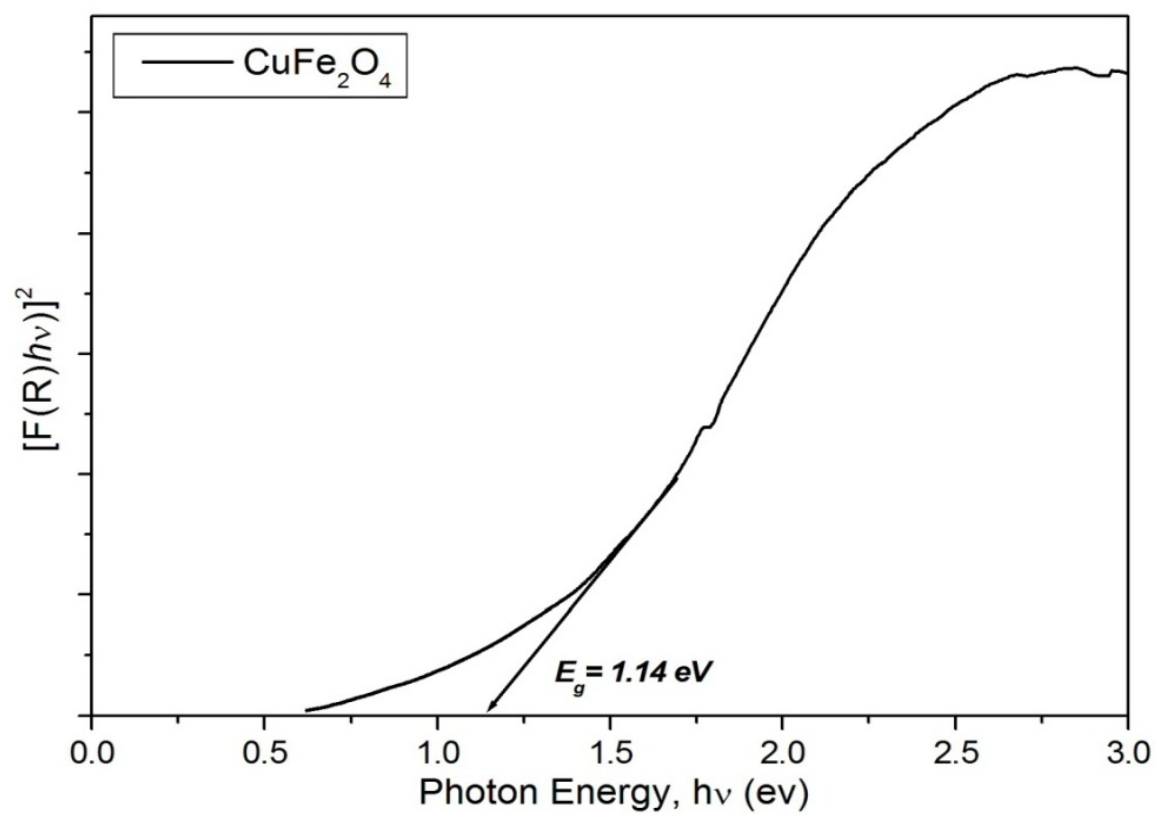

Fig. 4. Optical band gap energyof $\mathrm{CuFe}_{2} \mathrm{O}_{4}$ nanoparticles . 
TABLE 3. Magnetic properties of $\mathrm{CuFe}_{2} \mathrm{O}_{4}$ nanoparticles.

\begin{tabular}{|c|c|c|c|}
\hline Sample & $M s(\mathrm{em} \mu / \mathrm{g})$ & $\boldsymbol{M r}(\mathrm{em} \mu / \mathrm{g})$ & $\boldsymbol{H c} \times \mathbf{1 0}^{-3}(\mathrm{Oe})$ \\
\hline $\mathrm{CuFe}_{2} \mathrm{O}_{4}$ & 33.623 & 2.3627 & 71.489 \\
\hline
\end{tabular}

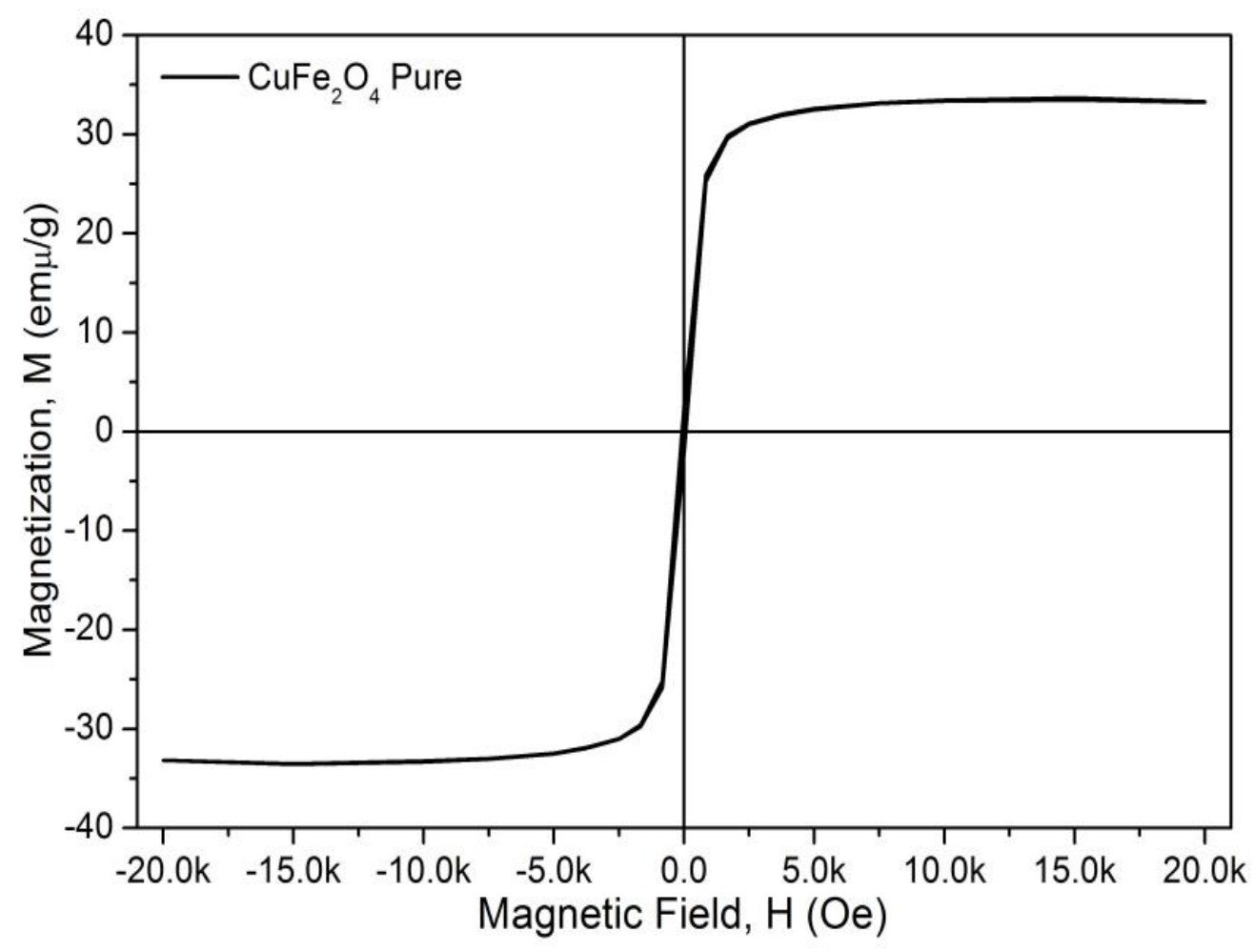

Fig. 5. M-H loops of $\mathrm{CuFe}_{2} \mathrm{O}_{4}$ nanopowders.

TABLE 4. Magnetic induction heating ability with different concentrations.

\begin{tabular}{|c|c|c|c|c|}
\hline Time (min) & $(20 \mathrm{mg} / \mathrm{ml})$ & $(40 \mathrm{mg} / \mathrm{ml})$ & $(60 \mathrm{mg} / \mathrm{ml})$ & $(80 \mathrm{mg} / \mathrm{ml})$ \\
\hline 0 & 32 & 32 & 32 & 32 \\
\hline 1 & 32.3 & 32.7 & 32.8 & 32.9 \\
\hline 2 & 32.7 & 33.6 & 33.3 & 34 \\
\hline 3 & 33.4 & 34.7 & 34 & 34.7 \\
\hline 4 & 34 & 35 & 35.1 & 35.3 \\
\hline 5 & 34.3 & 35.7 & 35.8 & 36.4 \\
\hline 6 & 35.1 & 35.8 & 36.5 & 37.1 \\
\hline 7 & 35.2 & 35.9 & 36.6 & 37.2 \\
\hline 8 & 35.7 & 36.5 & 36.8 & 37.6 \\
\hline 9 & 36.1 & 36.8 & 37.1 & 37.9 \\
\hline 10 & 36.9 & 37.2 & 37.9 & 38.1 \\
\hline
\end{tabular}

Egypt. J. Biophys. Biomed. Engng. Vol., 19 (2018) 


\section{The heating ability of the $\mathrm{Cu}-\mathrm{Fe} 2 \mathrm{O} 4$ dependent on the concentration}

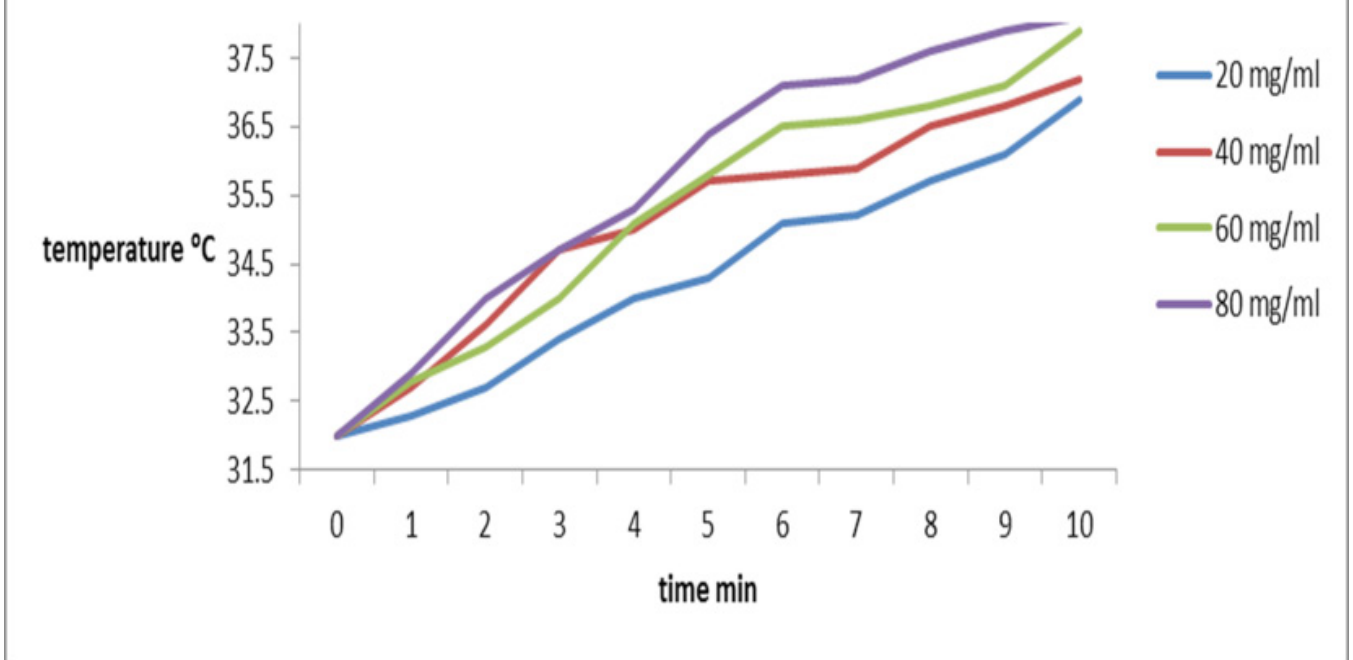

Fig. 6. Magnetic induction heating ability.

\section{Conclusion}

The degree to which magnetic hyperthermia can be applied to cancer therapy depends on the ability to deliver MNPs systematically to tumor cells in sufficient concentrations. The results indicate that a notice rise in temperature in short time induced by magnetic nanoparticles and the alternating magnetic field. Also, the heating ability of the magnetic nanoparticles was found to be strongly dependent on its concentration. The nanocrystalline $\mathrm{Cu}$ ferrite with the hyperthermia system is ready for killing tumor cells.

\section{Reference}

1. V.A.M. Brabers, Progress on spinel ferrite research, in: K. H. Buschow (Ed.), Hand Book of Magnetic Materials, vol.8, North-Holand, Amsterdam, 1995, p. 189.

2. M.A. Azooz, S.A.M. Abdel-Hameed, "Synthesis, characterization and magnetic properties of glass ceramics containing nanoparticles of both Ba-hexaferrite and Zn-ferrite", Ceramics International, 40, (2014), 4499-4505.

3. S.Chikazumi,S.Taketomi,M.Ukita,M.Mizukami, H. Miyajima, M.Setogawa, Y. Kurihara, "Physicsofmagneticfluids", J.Magn.Magn. Mater.,65, (1987), 245- 251.
4. A.H.Lu,W.Schmidt, N.M atoussevitch, H. Bonnemann, B.Splieth off, B.Tesche, E. Bill,W. Kiefer, F.Schuth, "Nanoengineering of amagnetically separable hydrogenation catalyst", Angew.Chem.In.Ed.43(2004)4303-4306.

5. S.C.Tsang,V.Caps,I.Paraskevas,D.Chadwick,D. Thompsett, "Magnetically separable", "carbonsupportednano catalysts for the manufacture offine chemicals", Angew.Chem.In.Ed., 43, (2004), $5645-5649$

6. Z.Zou,M.Ibisate, Y.Zhou, R.Aebersold,Y. Xia,H.Zhang, "Synthesisand evaluation of superparam agneticsilicaparticles for extraction of glycopeptides inthemicrotiterplateformat", Anal. Chem.80(2008)1228-1234.

7. Q.A.Pankhurst, N.K.T.Thanh,S.K.Jones, J. Dobson, "Progressinapplicationof magnetic nanoparticlesinbiomedicine",J.Phys.D:Appl. Phys., 43, (2009), 224001-224015.

8. S.Mornet, S.Vasseur,F.Grasset,P.Veverka, G. Goglio,A.Demourgues,J. Portier, E.Pollert,E. Duguet, "Magneticnanoparticledesignformedical applications", Prog.SolidStateChem., 34, (2006), 237-247.

9. Z.Li,L.Wei,M.Gao,H.Lei, “One-potreactiontosynt hesizebiocompatible magnetic nanoparticles",Adv. Mater., 17, (2005), 1001-1005. 
10. H.Luo,D.Wang,J.He,Y.Lu, "Magneticcobaltna nowirethinfilms",J.Phys. Chem. B., 109(2005), 1919-1922.

11. YuanPu, Xia Tao, XiaofeiZeng, Yuan Le, JianFeng Chen, "Synthesis of $\mathrm{Co}-\mathrm{Cu}-\mathrm{Zn}$ doped $\mathrm{Fe}_{3} \mathrm{O}_{4}$ nanoparticles with tunable morphology and magnetic properties", Journal of Magnetism and Magnetic Materials, 322, (2010), 1985-1990.

12. D. L. L. P e 1 e c k y, R. D . R i e k e , "Magneticpropertiesofnanostructured materials", Chem. Mater., 8, (1996), 1770-1783.

13. B.T. Naughton, D.R. Clarke, "CompositionSize Effects in Nickel-Zinc Ferrite Nanoparticles Prepared by Aqueous Coprecipitation", J. Am. Ceram. Soc., 91(11) (2008), 1253-1257.

14. J. Azadmanjiri, S.A.S.Ebrahimi, "Influence of stoichiometry and calcination condition on the microstructure and phase constitution of $\mathrm{NiFe}_{2} \mathrm{O}_{4}$ powders prepared by sol-gel autocombustion method", Phys. Stat. Sol. (c), 1, (2004), 3414-3417.

15. S.M. Li, Q. Wang, A.B. Wu, "Magnetic properties of $\mathrm{Fe} x \mathrm{Co} 1-x / \mathrm{Co} y \mathrm{Fe} 1-y \mathrm{Fe} 2 \mathrm{O} 4$ composite under hydrothermal condition", Curr. Appl. Phys., 9, (2009), 1386-1392.

16. H.E. Zhang, B.F. Zhang, G.F. Wang, X.H. Dong, Y. Gao, "The structure and magnetic properties of $\mathrm{Zn}_{1-x} \mathrm{Ni}_{x} \mathrm{Fe}_{2} \mathrm{O}_{4}$ ferrite nanoparticles prepared by sol-gel auto-combustion”, J. Magn. Magn. Mater., 312, (2007), 126-130.

17. A.C.F.M. Costa, V.J. Silva, D.R. Cornejo, M.R. Morelli, R.H.G.A. Kiminami, L. Gama, "Magnetic and structural properties of $\mathrm{NiFe}_{2} \mathrm{O}_{4}$ ferrite nanopowder doped with Zn2+", J. Magn. Magn. Mater., 320, (2008), 370-372.

18. A.C.F.M. Costa, A.M.D. Leite, H.S. Ferreira," Brown pigment of the nanopowder spinel ferrite prepared by combustion reaction", J. Eur. Ceram. Soc., 28 (2008) 2033-2037.

19. M. Gharagozlou, "Synthesis, characterization and influence of calcination temperature on magnetic properties of nanocrystalline spinel Co-ferrite prepared by polymeric precursor method", J. Alloys Compd., 486, (2009), 660-665.

20. J.L. Zhang, J.X. Shi, M.L. Gong, "Synthesis of magnetic nickel spinel ferrite nanospheres by a reverse emulsion-assisted hydrothermal process", J. Solid State Chem., 182, (2009), 2135-2140.
21. M. Jalaly, M.H. Enayati, F. Karimzadeh, "Investigation of structural and magnetic properties of nanocrystalline $\mathrm{Ni}_{0.3} \mathrm{Zn}_{0.7} \mathrm{Fe}_{2} \mathrm{O}_{4}$ prepared by high energy ball milling", J. Alloys Compd., 480, (2009), 737-740.

22. S. Dasgupta, K.B. Kim, J. Ellrichc, "Mechanochemical synthesis and characterization of microstructure and magnetic properties of nanocrystalline $\mathrm{Mn}_{1-x} \mathrm{Zn}_{x} \mathrm{Fe}_{2} \mathrm{O}_{4}$," J. Alloys Compd., 424, (2006), 13-20.

23. H.M.Xiao,X.M.Liu,S.Y.Fu, "Synthesis,magne ticandmicrowaveabsorbing properties ofcoreshellstructuredMnFe $\mathrm{O}_{4} / \mathrm{TiO} 2$ nanocomposites", Compos. Sci. Technol., 66, (2006), 2003-2008.

24. A. Dogra, R. Kumar, N. Kumar, P. Sen, M Singh, "Structural and magnetic studies of $\mathrm{NiMn}_{005} \mathrm{Ti}_{x} \mathrm{Mg}_{x} \mathrm{Fe}_{195-2 x} \mathrm{O}_{4}$ ferrite", Mater. Sci. Eng. $\mathrm{B}, 110,(2004), 243-250$.

25. M.N.Ashiq, S. Saleem, M.A. Malana, A.U. Rehman, "Physical, electrical and magnetic properties of nanocrystallineZr-Ni dopedMnferrite synthesized by the co-precipitation method", J. Alloys Compd.,486, (2009), 640-644.

26. S. Kumar, R. Kumar, S.K. Sharma, V.R. Reddy, A. Banerjee, Alimuddin, "Temperaturedependent Mössbauer and dielectric studies of $\mathrm{Mg}_{0.95} \mathrm{Mn}_{0.05} \mathrm{Fe}_{1.0} \mathrm{Ti}_{10} \mathrm{O}_{4}$ ", Solid StateCommun., 142, (2007), 706-709.

27. D.S. Birajdar, D.R. Mane, S.S. More, V.B. Kawade, K.M. Jadhav, "Structural and magnetic properties of $\mathrm{Zn}_{x} \mathrm{Cu}_{1.4-x} \mathrm{Mn}_{0.4} \mathrm{Fe}_{1.2} \mathrm{O}_{4}$ ferrites", Mater. Lett. 59, (2005) 2981-2985.

28. L. Nalbandian, A. Delimitis, V.T. Zaspalis, E.A Deliyanni, D.N. Bakoyannakis, E.N.Peleka, "Hydrothermally prepared nanocrystallineMnZn ferrites: Synthesis and characterization", J. Micropor. Mesopor. Mater., 114, (2008), 465-473.

29. M.K. Shobana, S. Sankar, V. Rajendran, "Characterization of $\mathrm{Co}_{05} \mathrm{Mn}_{05} \mathrm{Fe}_{2} \mathrm{O}_{4}$ nanoparticles", Mater. Chem. Phys., 113, (2009), 10-13.

30. A.M.M. Farea, S. Kumar, K.M. Batoo, A. Yousef, C.G. Lee, Alimuddin, "Influence of the doping of Ti4+ ions on electrical and magnetic properties of $\mathrm{Mn}_{1+x} \mathrm{Fe}_{2-2 x} \mathrm{Ti}_{x} \mathrm{O}_{4}$ ferrite", J. AlloysCompd., 469, (2009), 451-457.

31. D.A. Rayan, A.M. Elseman, M.M. Rashad, "Remarkable impact of $\mathrm{Ni}^{2+}$ ion on the structural, optical, and magnetic properties of hexagonal wurtziteZnSnanopowders", Applied Physics A, 124, (2018), 659.

32. M.M. Hessien, D.A. Rayan, M.H.H. Mahmoud, 
A. Alhadhrami, M.M. Rashad, "Controlling the structural, microstructure and magnetic properties of barium w-type hexaferrite elaborated using tartaric acid precursor strategy", Journal of Materials Science: Materials in Electronics, 29(12), (2018), 9771-9779.

33. M.M. Rashad, D.A. Rayan, M. EL-Gendy, T.A. Taha, M.M. Elkholy, "Structural and Magnetic Properties of Hexaferrite $\mathrm{Ba}_{2} \mathrm{Co}_{2} \mathrm{Fe}_{12} \mathrm{O}_{22}$ Nanopowders Prepared Using Two Chemical Methods", Journal of Superconductivity and Novel Magnetism, (2018), 1-8.

34. M.M. Rashad,A. Khalifa, D.A. Rayan, M.G. Fayed, "Superparamagnetic $\mathrm{Cu} 2+$ substituted $\mathrm{Mn}-\mathrm{MgFe}_{2} \mathrm{O}_{4}$ powders prepared through coprecipitation strategy: Structural, microstructure and magnetic properties", J. Mater. Sci.: Mater. Electron., 29(4), (2018), 3391-3400.

35. M.M. Rashad, D.A. Rayan, A.O. Turky, M.M. Hessien, "Effect of $\mathrm{Co}^{2+}$ and $\mathrm{Y}^{3+}$ ions insertion on the microstructure development and magnetic properties of $\mathrm{Ni}_{0.5} \mathrm{Zn}_{0.5} \mathrm{Fe}_{2} \mathrm{O}_{4}$ powders synthesized using co-precipitation method", J. Magn. Magn. Mater., 374, (2015), 359-366.

36. D.A. Rayan, Y.H. Elbashar, A.B. El Basaty, M.M. Rashad, "Infrared spectroscopy of cupric oxide doped barium phosphate glass", Research Journal of Pharmaceutical, Biological and Chemical Sciences (RJPBCS), 6(3), (2015), 1026-1030.

37. M.M. Rashad, D.A. Rayan, A.A. Ramadan, "Optical and magnetic properties of $\mathrm{CuO} /$ $\mathrm{CuFe}_{2} \mathrm{O}_{4}$ nanocomposites”, J. Mater. Sci.: Mater. Electron., 24, (2013), 2742-2749.

38. M.M. Rashad, S. Soltan, A.A. Ramadan, M.F. Bekheet, D.A. Rayan, "Investigation of the structural, optical and magnetic properties of $\mathrm{CuO} /$ $\mathrm{CuFe}_{2} \mathrm{O}_{4}$ nanocomposites synthesized via simple microemulsion method", Ceramics International, 41(9) part B, (2015), 12237-12245.

39. A.M. Elseman, D.A. Rayan, M.M. Rashad, "Structure, optical and magnetic behavior of nanocrystallineCuO powders synthesized via a new technique using Schiff base complex", J. Mater. Sci.: Mater. Electron., 27(3), (2016), 26522661.

40. S.M. Abdelbasir, S.M. El-Sheikh, M.M. Rashad, D.A. Rayan, "Controlling the optical and magnetic properties of nanostuctured cuprous oxide synthesized from waste electric cables", Electronic Materials Letters, 14(4), (2018), 1-12.
41. M.M. Rashad, A.A. Ibrahim, D.A. Rayan, M.M.S. Sanad, I.M. Helmy, "Photo-fenton-like degradation of rhodamine $\mathrm{B}$ dye from waste water using iron molybdate catalyst under visible light irradiation", Environmental Nanotechnology, Monitoring \& Management, 8, (2017), 175-186.

42. M.M. Rashad, A.G. Mostafa, B.W. Mwakikunga, D.A. Rayan, "Tunable optical properties of some rare earth elements doped mayenite Ca12A114O33 nanopowders elaborated by oxalate precursor route", Applied Physics A, 123:42, (2017), 1-7.

43. M.M. Rashad, A.G. Mostafa, D.A. Rayan, "Structural and optical properties of nanocrystallinemayenite Ca12A114O33 powders synthesized using a novel route", J. Mater. Sci.: Mater. Electron., 27(3), (2016), 2614-2623.

44. E.M.M. Ewais, D.H.A. Besisa, A.A.M. El-Amir, S.M. El-Sheikh, D.E. Rayan, "Optical properties of nanocrystalline magnesium aluminate spinel synthesized from industrial wastes", Journal of Alloys and Compounds, 649, (2015), 159-166.

45. Gilchrist RK, Medal R, Shorey WD, Hanselman RC, Parrott JC, Taylor CB, "Selective inductive heating of lymph nodes", Ann. Surg., 146, (1957), 596-606.

46. A. Jordan, R. Scholz, K. Maier-Hau, M. Johannsen, P. Wust, J. Nadobny, H. Schirra, H. Schmidt, S. Deger, S. Loening, W. Lanksch, R. Felix, "Presentation of a new magnetic field therapy system for the treatment ofhuman solid tumors with magnetic fluid hyperthermia", J.Magn.Magn. Mat., 225, (2001), 118-126.

47. R.E.Rosensweig,"Heating magnetic fluid with alternating magnetic field",J.Magn.Magn. Mat., 252, (2002), 370-374.

( Rrceived 19/9/2018; accepted 18/1/2019) 


$$
\begin{aligned}
& \text { الدر اسفة الخو اص المغناطيسية و انتاج الحر ارة اللازمه لعلاج الأور ام باستخدام درجات الحر ارة }
\end{aligned}
$$

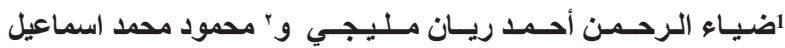

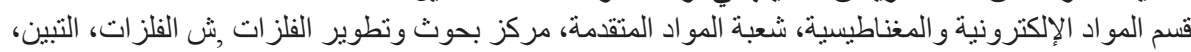

$$
\begin{aligned}
& \text { حلوان † قسم الفيزياء, كلية العلوم بنين- جامعة الاز هر بالقاهرة ـ مصر. }
\end{aligned}
$$

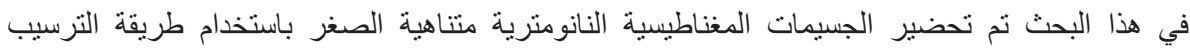

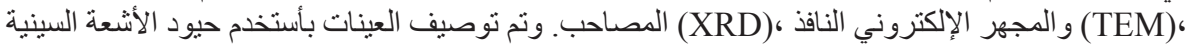

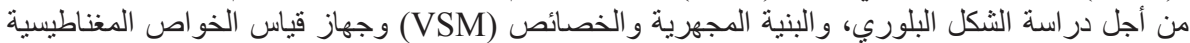

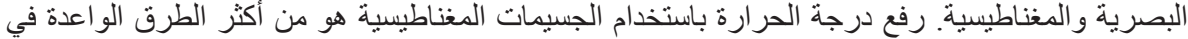

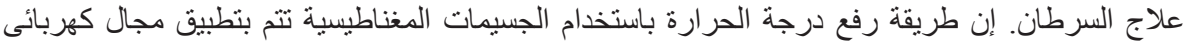

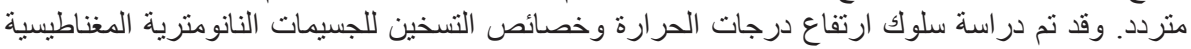

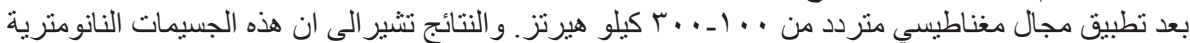

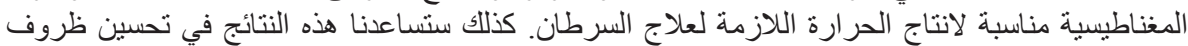

معالجة الاورام السرطانية 